\title{
NADPH oxidases as potential pharmacological targets against increased seizure susceptibility after systemic inflammation
}

Wan-Yu Huang ${ }^{1,2}$, Shankung Lin ${ }^{3}$, Hsuan-Ying Chen ${ }^{3}$, Ya-Ping Chen ${ }^{3}$, Ting-Yu Chen ${ }^{3}$, Kuei-Sen Hsu ${ }^{1 *}$ and Hung-Ming $\mathrm{Wu}^{3,4,5^{*}}$

\begin{abstract}
Background: Systemic inflammation associated with sepsis can induce neuronal hyperexcitability, leading to enhanced seizure predisposition and occurrence. Brain microglia are rapidly activated in response to systemic inflammation and, in this activated state, release multiple cytokines and signaling factors that amplify the inflammatory response and increase neuronal excitability. NADPH oxidase (NOX) enzymes promote microglial activation through the generation of reactive oxygen species (ROS), such as superoxide anion. We hypothesized that NOX isoforms, particularly NOX2, are potential targets for prevention of sepsis-associated seizures.

Methods: To reduce NADPH oxidase 2-derived ROS production, mice with deficits of NOX regulatory subunit/NOX2

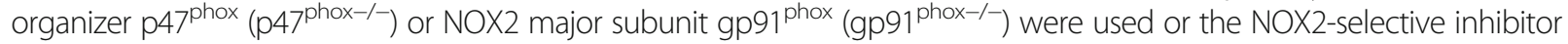
diphenyleneiodonium (DPI) was used to treat wild-type (WT) mice. Systemic inflammation was induced by intraperitoneal injection of lipopolysaccharide (LPS). Seizure susceptibility was compared among mouse groups in response to intraperitoneal injection of pentylenetetrazole (PTZ). Brain tissues were assayed for proinflammatory gene and protein expression, and immunofluorescence staining was used to estimate the proportion of activated microglia.

Results: Increased susceptibility to PTZ-induced seizures following sepsis was significantly attenuated in

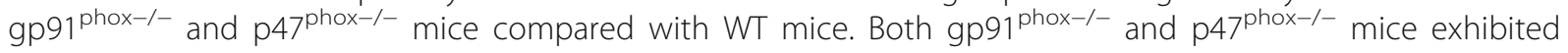
reduced microglia activation and lower brain induction of multiple proconvulsive cytokines, including TNFa, IL-1 $\beta, I L-6$, and CCL2, compared with WT mice. Administration of DPI following LPS injection significantly attenuated the increased susceptibility to PTZ-induced seizures and reduced both microglia activation and brain proconvulsive cytokine concentrations compared with vehicle-treated controls. DPI also inhibited the upregulation of gp91 ${ }^{\text {phox }}$ transcripts following LPS injection.

Conclusions: Our results indicate that NADPH oxidases contribute to the development of increased seizure susceptibility in mice after sepsis. Pharmacologic inhibition of NOX may be a promising therapeutic approach to reducing sepsis-associated neuroinflammation, neuronal hyperexcitability, and seizures.
\end{abstract}

Keywords: NADPH oxidase, Diphenyleneiodonium, Lipopolysaccharide, Seizure, Cytokine, Neuroninflammation

\footnotetext{
*Correspondence: richard@mail.ncku.edu.tw; 18288@cch.org.tw

${ }^{1}$ Institute of Basic Medical Sciences, College of Medicine, National Cheng

Kung University, Tainan, Taiwan

${ }^{3}$ Inflammation Research \& Drug Development Center, Changhua Christian

Hospital, Changhua, Taiwan

Full list of author information is available at the end of the article
}

(c) The Author(s). 2018 Open Access This article is distributed under the terms of the Creative Commons Attribution 4.0 International License (http://creativecommons.org/licenses/by/4.0/), which permits unrestricted use, distribution, and reproduction in any medium, provided you give appropriate credit to the original author(s) and the source, provide a link to the Creative Commons license, and indicate if changes were made. The Creative Commons Public Domain Dedication waiver (http://creativecommons.org/publicdomain/zero/1.0/) applies to the data made available in this article, unless otherwise stated. 


\section{Background}

Seizure is a common acute complication of sepsis and ensuing systemic inflammation, particularly in neonates and infants $[1,2]$. Seizures are caused by genetic factors or acquired clinical pathologies that disrupt the excitatory/inhibitory balance within brain circuits. During inflammation, it is believed that hyperexcitation of neurons, resulting from the release of signaling factors such as cytokines and reactive oxygen species (ROS), leads to enhanced seizure predisposition [3-5] and subsequent neuroplastic changes and neurodegeneration, which may eventually induce a chronic seizure syndrome $[6,7]$.

Growing evidence indicates that transient systemic inflammation can alter neuronal properties and behavior, particularly during critical periods of brain development, resulting in programmed neuron death in adulthood. For instance, a single intraperitoneal (i.p.) injection of the potent immune system activator lipopolysaccharide (LPS) administered to postnatal rats can cause increased seizure susceptibility [7] and alter NMDA receptor subunit mRNA expression in the adult brain [8]. Qin and colleagues also reported that a single systemic LPS injection to adult mice induced chronically persistent activation of microglia and progressive loss of dopaminergic neurons in the substantia nigra [6]. Although brief peripheral inflammation usually does not damage the mature brain, it can induce transient functional deficits in behavior and an acute inflammatory response in the brain similar in some respects to that in the periphery, including elevation of the same proinflammatory cytokines $[9,10]$. This induced neuroinflammation can be transient or long-lasting depending on the age at insult $[6,7,11-13]$. Collectively, such studies indicate that both immature and mature brains can be permanently modified after a single brief episode of systemic inflammation, resulting in increased neuronal excitability and behavior changes.

Microglia, the resident macrophage-like immune cells of the central nervous system (CNS), sense local pathological changes, induce and amplify the inflammatory response, and exert additional neuromodulatory effects through dynamic regulation of astroglial activity [14]. In response to systemic inflammation, microglia become activated and may then damage neurons through excessive production and release of neurotoxic factors, including proinflammatory cytokines and ROS. Both clinical reports and experimental studies in vivo and in vitro suggest that these cytokines may increase neuronal excitability and seizure susceptibility [15]. Riazi and colleagues reported that microglia-derived TNF $\alpha$ contributes to neuronal hyperexcitability and exacerbates pentylenetetrazole (PTZ)-induced seizures following peripheral inflammation [4]. Conversely, inhibition of action of the cytokine interleukin (IL)- $1 \beta$ in the brain by application of an exogenous IL-1 receptor antagonist (IL-1ra) or by enhancing endogenous IL-1ra expression can suppress seizure induction or reduce seizure severity in animal models [16-18]. In addition to tumor necrosis factor alpha (TNF $\alpha)$ and IL-1, cytokines reported to modulate neuronal excitability and seizure susceptibility include IL-6 [19, 20], monocyte chemoattractant protein-1 (MCP-1/CCL2) [5], IL-10 [21], and IL-12 [21].

NADPH oxidase 2 (NOX2), also called phagocytic NADPH oxidase (PHOX), is a member of the NADPH oxidase (NOX) family of enzymes implicated in phagocytic bactericidal and fungicidal activities through ROS production. NOX enzymes, principally NOX2, are also involved in microglia activation. When microglial NOX2 is activated, several ROS including superoxide anion $\left(\mathrm{O}_{2}{ }^{--}\right)$, hydroxyl radical $\left(\mathrm{OH}^{--}\right)$, lipid hydroperoxides, and byproducts (e.g., $\mathrm{H}_{2} \mathrm{O}_{2}$ ), are generated that can directly damage neurons through extracellular pathways as well as induce further ROS generation and the expression of proinflammatory genes such as IL- $1 \beta$, TNF $\alpha$, and inducible nitric oxide synthase (iNOS) $[22,23]$.

We hypothesized that phagocytic NADPH oxidase (NOX2) within the brain, mainly expressed in microglia, plays an essential role in increased neuronal excitability following systemic inflammation. While targeting inflammation has long been proposed as a potential therapeutic strategy for prevention of neuroinflammation-associated seizures [18, 24-26], there are few studies showing that this is an effective approach. Therefore, the main purpose of this study was to investigate whether NOX2 plays a critical role in seizure susceptibility after systemic inflammation and whether post-treatment with the widely used and longacting NOX2 inhibitor, diphenyleneiodonium (DPI) [27], can attenuate the enhanced seizure susceptibility induced by systemic inflammation. By comparing seizure susceptibility among mice genetically deficient in NOX2 complex subunits gp $91^{\text {phox }}$ and $\mathrm{p} 47^{\text {phox }}$, DPI-treated mice, and wild types (WT), we demonstrate that NOX2-derived ROS contribute to neuronal hyperexcitability and the increased seizure susceptibility following LPS-induced inflammation. Thus, pharmacological NOX2 blockade is a potential therapeutic strategy for prevention of sepsis-associated seizures.

\section{Methods}

Animals and lipopolysaccharide-induced sepsis model Male C57BL/6J mice (8-9 weeks old, 25-30 g) were purchased from the National Lab Animal Center (Taiwan). The NOX2 subunit knockout mice B6.129S6Cybbtm1Din/J mice (gp91 ${ }^{\text {phox-/- }}$, JAX stock 002365) and $\mathrm{B} 6(\mathrm{Cg})-\mathrm{Ncf} 1<\mathrm{m} 1 \mathrm{~J}>/ \mathrm{J}$ mice $\left(\mathrm{p} 47^{\text {phox-/-}}\right.$, JAX Stock 004742) were obtained from The Jackson Laboratory (Bar Harbor, ME, USA). The $\mathrm{PHOX}^{-/-}$mutation is maintained on a C57BL/6J background; therefore, $\mathrm{C} 57 \mathrm{BL} / 6 \mathrm{~J}\left(\mathrm{PHOX}^{+/+}\right)$mice were used as control animals 
for this study. The animals were housed in a specific pathogen-free room at $21{ }^{\circ} \mathrm{C}$ under a $12-\mathrm{h} / 12$-h artificial light/dark cycle with free access to feed. Experiments were performed using age- and weight-matched male animals. All procedures were approved by the Animal Care and Use Committee of Changhua Christian Hospital. The mouse model of sepsis was induced by intraperitoneal (i.p.) injection of $4 \mathrm{mg} / \mathrm{kg}$ lipopolysaccharide (LPS), modified from a previous study in mice [28]. In total, 352 of mice were used in this study, including 248 of WT mice, 52 of p $47^{\text {phox-l- }}$ mice, and 52 of gp $91^{\text {phox-/- }}$ mice.

\section{Diphenyleneiodonium treatment}

Diphenyleneiodonium (DPI) (Sigma-Aldrich, St. Louis, MO, USA) is a pharmacological inhibitor of NADPH oxidase. In the present study, we assessed the efficacy of DPI against PTZ-induced seizure susceptibility in LPStreated mice. Diphenyleneiodonium was injected i.p. at a dose of $0.01,0.1$, or $1 \mathrm{mg} / \mathrm{kg}$ at indicated time points after LPS injection.

\section{Determination of seizure susceptibility to pentylenetetrazol}

To assess seizure susceptibility, mice were injected i.p. with $60 \mathrm{mg} / \mathrm{kg}$ pentylenetetrazole (PTZ) $48 \mathrm{~h}$ after LPS or vehicle treatment (Sigma, St. Louis, MO, USA). Pentylenetetrazole may have multiple mechanisms of action in neurons, one of which is strongly correlated with its affinity for the picrotoxin binding site on the $\mathrm{GABA}_{\mathrm{A}}$ receptor complex [29, 30]. Seizure activity was video recorded during an observation period of $2 \mathrm{~h}$ after PTZ injection. Behavioral seizures were scored every 5 min according to a previously defined scale [31, 32] as follows: stage 1 (exploring, sniffing, and grooming ceased and immobility); stage 2 (forelimb and/or tail extension, appearance of a rigid posture); stage 3 (isolated myoclonic jerks, with brief twitching movements); stage 4 (forelimb clonus and partial rearing); stage 5 (forelimb clonus, rearing, and falling); and stage 6 (generalized tonic-clonic activity with loss of postural tone, often resulting in death).

\section{Plasma levels of TNFa after peritoneal LPS administration}

To assess the acute effects of LPS on systemic inflammation, blood samples were obtained from the cheek of the wild-type and NOX2 knockout mice $1 \mathrm{~h}$ after LPS injection $(4 \mathrm{mg} / \mathrm{kg}$, i.p.). The plasma samples were stored at $-80^{\circ} \mathrm{C}$ until they were assayed for TNF $\alpha$ concentration according to the manufacturer's instructions (Duo set kit; R\&D Systems, Minneapolis, MN, USA).

\section{Microglia-enriched cultures}

Primary enriched-microglial cultures were prepared from WT, gp91 ${ }^{\text {phox-1- }}$, and $\mathrm{p} 47^{\text {phox-/- }}$ pups using a previously described protocol $[28,33]$. Briefly, the whole brain obtained from a 0-1-day-old mouse pup was carefully removed, and the olfactory bulbs, cerebellum, brain stem, meninges, and blood vessels were separated. The remaining brain tissue was triturated into a singlecell suspension, which was then centrifuged at $500 \times g$ for $6 \mathrm{~min}$ at $4{ }^{\circ} \mathrm{C}$. The pellet was resuspended in the warm mixed glial culture maintenance medium. The cells were cultured with a seeding density of five brains per 175$\mathrm{cm}^{2}$ flask. The culture medium was refreshed every 3 days. Approximately 14-16 days later, microglia were shaken out at $180 \mathrm{rpm}$ for $30 \mathrm{~min}$ to $1 \mathrm{~h}$ at $37^{\circ} \mathrm{C}$. After centrifugation, the resuspended microglia were seeded in a 24-well plate at a density of $7.5 \times 10^{4} /$ well. After storage overnight, cells were treated with LPS $(5 \mathrm{ng} / \mathrm{ml})$, TNF $\alpha(500 \mathrm{pg} / \mathrm{ml})$, or IL- $1 \beta(500 \mathrm{pg} / \mathrm{ml})$. The purity of microglia was $>98 \%$, confirmed by staining with $\mathrm{F} 4 / 80$ antibody.

\section{Western blotting analysis}

For protein lysate extraction, dissected mouse brain tissue (e.g., hippocampus) was homogenized and lysed in ice-cold modified radioimmunoprecipitation assay (RIPA) buffer containing $50 \mathrm{mM}$ Tris- $\mathrm{HCl}(\mathrm{pH} 7.4), 1 \%$ Nonidet P-40, $150 \mathrm{mM} \mathrm{NaCl}, 1 \mathrm{mM}$ EDTA, $1 \mathrm{mM}$ phenylmethylsulfonyl fluoride, $10 \mu \mathrm{g} / \mathrm{ml}$ each of aprotinin, leupeptin, and pepstatin, $1 \mathrm{mM} \mathrm{Na}_{3} \mathrm{VO}_{4}$, and $1 \mathrm{mM}$ $\mathrm{NaF}$. Immunobloting analysis was performed as described $[28,33]$. Briefly, total proteins from each sample were fractionated by SDS-PAGE and then transferred to polyvinylidene difluoride (PVDF) membranes. Membranes were probed with antibodies against the proteins including gp91 (Cat\# sc-5827) and $\beta$-actin(Cat\# sc-47,778) (the gen loading control) from Santa Cruz Biotechnology (Dallas, TX), Cruz, iba-1(Cat\# GTX100042), GFAP(Cat\# GTX85454) and BDNF(GTX62495) from GeneTex Biotechnology (Irvine, CA), and hsp 90 (Cat\# 4877) (the gel loading control) from Cell Signaling Technology (Danvers, MA) at 1/1000 dilution. Immunoblotted membranes were then washed for $10 \mathrm{~min}$ in $0.1 \%$ Tris-buffered saline-Tween 20 (TBST), incubated in horseradish peroxidase (HRP)-conjugated secondary antibody (1/10,000 dilution) for $1 \mathrm{~h}$, and washed again in TBST. Signals were visualized and quantified using the GeneGnome chemiluminescence imaging system (Syngene, Maryland).

\section{Measurement of cytokines in brain supernatant}

Total brain proteins were extracted using a protocol modified from previous studies on cytokine/chemokine panels [10, 34]. Briefly, temporal lobe tissue was weighed and homogenized with a bench top homogenizer (Kinematica, Switzerland) in a $5 \times$ volume of extraction buffer containing $20 \mathrm{mM}$ Tris $\mathrm{HCl}, 0.15 \mathrm{M} \mathrm{NaCl}, 2 \mathrm{mM}$ EDTA, $1 \mathrm{mM}$ EGTA, and Protease Inhibitor Cocktail 
(Sigma, St. Louis, MO). Samples were centrifuged at $1000 \times g$ for $10 \mathrm{~min}$ at $4{ }^{\circ} \mathrm{C}$, and the supernatants were centrifuged again at $20,000 \times g$ for $40 \mathrm{~min}$ at $4{ }^{\circ} \mathrm{C}$ to remove any remaining debris. Protein concentration was measured using a BCA Protein Assay Kit (Pierce Biotechnology, Rockford, IL). All cytokine and chemokine measurements were performed using MERCK Millipore Presents MILLIPLEX ${ }^{\circledast}$ MAP multiplex Assays (St. Charles, MO, USA) by the procedures reported previously [10, 34]. Concentrations of TNF $\alpha$, IL-1 $\beta$, IL-6, CCL2, IL-10, and IL-12 were simultaneously determined in brain samples using a LINCOplexTM mouse cytokine kit and a Luminex 200 reader (Luminex Corp., Austin, TX, USA). Concentrations were calculated by generating a calibration curve using recombinant cytokines diluted in brain sample extraction buffer and StatLIAs software (Brendan Scientific Corp., Carlsbad, CA, USA). Cytokine and chemokine concentrations were then normalized to total protein for each sample.

\section{Real-time RT-PCR analysis}

To assess the expression of proinflammatory factors TNF $\alpha$, IL-1 $\beta$, IL-6, CCL2, IL-10, and IL-12, and gp91 in response to LPS-induced systemic inflammation, mouse brains were prepared at the indicated time points following LPS treatment. Total RNA was prepared from temporal lobe tissues using the RNeasy micro kit (Qiagen, Valencia, CA, USA) and reverse transcribed into cDNA using the Super Script-III First-strand Synthesis System kit (Invitrogen, Carlsbad, CA, USA). Real-time PCR was performed using the Rotor-Gene $\mathrm{Q}$ cycler (Qiagen, Valencia, CA, USA) according to the manufacturer's protocol. All experiments were conducted in triplicate using TaqMan Gene Expression Master mix (Applied Biosystems) and TaqMan Gene Expression Assays, with optimized primer and TaqMan MGB probe sets (Applied Biosystems, Foster City, CA, USA). The PCR primer pairs and TaqMan MGB probes (assay-IDs) (Applied Biosystems) were as follows: Mm00443260_gl (TNF $\alpha$ ), Mm00434228_ml (IL-1ß), Mm00446190_ml (IL-6), Mm00441242_ml (CCL2), Mm01288386_ml (IL-10), Mm00434174_ml (IL-12b), and Mm00607939Msl ( $\beta$-actin). A total of 40 cycles of PCR was performed as follows: activation of AmpliTaq Gold Enzyme (10 min at $95^{\circ} \mathrm{C}$ ), denaturation $\left(15 \mathrm{~s}\right.$ at $\left.95{ }^{\circ} \mathrm{C}\right)$, and annealing/extension $\left(1 \mathrm{~min}\right.$ at $\left.60{ }^{\circ} \mathrm{C}\right)$. Relative expression levels were calculated using the comparative threshold cycle ( $\mathrm{Ct}$ value) method and normalized to the $\Delta \mathrm{Ct}$ of $\beta$-actin.

\section{Immunofluorescence staining}

To assess the effects of LPS-induced systemic inflammation on CNS glia, mouse brain sections were prepared for immunostaining. Mice were deeply anesthetized and perfused with $4 \%$ paraformaldehyde (PFA) $24 \mathrm{~h}$ after vehicle or LPS treatment. The brain was dissected and post-fixed overnight in
$4 \%$ PFA at $4{ }^{\circ} \mathrm{C}$. Coronal frozen sections (30 $\mu \mathrm{m}$ thick) through hippocampi were prepared as described [28]. Brain sections were permeabilized with $1 \%$ Triton X-100 in PBS for $10 \mathrm{~min}$ and then blocked in $1 \%$ bovine serum albumin in PBST for $1 \mathrm{~h}$. To identify microglia, slices were incubated overnight at $4{ }^{\circ} \mathrm{C}$ in blocking buffer containing an antibody against ionized calcium binding adaptor molecule 1 protein (iba-1) (Cat\# GTX100042) from GeneTex Biotechnology (Irvine, CA), at 1/200 dilution. The brain sections were then also incubated with donkey anti-rabbit-FITC antibody (1200) at room temperature for $1 \mathrm{~h}$. Sections were then counterstained with 4', 6-diamidino-2-phenylindole (DAPI) for $5 \mathrm{~min}$ at room temperature and observed by fluorescence microscopy. Microglial activation was determined by morphology changes from round and small (resting state) to rod- and/or amoeboid shaped with a significant enlargement of cell size (activated state). We used a stereological approach to count the number of resting and activated microglia from three sections of the hippocampus per mouse ( $n=3$ mice/group), including dentate gyrus (DG) and CA3 subregions on a ZEISS-Axio Observer Z1, HAL 100 microscope (ZEISS, Germany) under bright-field optics $[33,35]$. Briefly, images were taken from DG and CA3 subregions at -2.18 to $-2.54 \mathrm{~mm}$ from the bregma. Coordinates for the DG were taken centered from 1.4 to $1.7 \mathrm{~mm}$ medial and 1.7 to $1.9 \mathrm{~mm}$ ventral. Coordinates for the CA3 were from 2.1 to $2.4 \mathrm{~mm}$ medial and from 1.8 to $2.1 \mathrm{~mm}$ ventral. Activated microglia were distinguished from resting microglia by the presence of shorter, less-ramified processes and rod-and/or amoeboid appearance. Quantification of microglia was done by a single experimenter who was blind to each animal's treatment, by counting the total number of iba- 1 positive cells at $200 \times$ magnification in a rectangular region of interest $\left(300 \times 400 \mu \mathrm{m}^{2}\right)$. Results are presented as means \pm standard error of the mean (SEM) in the counted area.

\section{Statistical analysis}

Values are presented as mean \pm SEM. Paired group means were compared by Student's $t$ test. The efficacy of NOX2 deletion or DPI treatment against PTZ-induced seizure severity was assessed by two-way repeated measures ANOVA, adjusted by Bonferroni tests. Multiple group means were compared by one-way ANOVA, followed by Bonferroni post hoc tests. All analyses were conducted using the software GraphPad Prism 7 (La Jolla, CA). Differences were considered significant at $p<0.05$.

\section{Results}

NOX2 deletion reduces the increased seizure susceptibility to pentylenetetrazole following LPS-induced systemic inflammation

To elucidate the role of NOX2 in seizure incidence following systemic inflammation, we induced systemic 
inflammation in adult (8-9-week-old) wild-type, gp91 $1^{\text {phox-I- }}$, and $\mathrm{p} 47^{\text {phox-/- }}$ mice with a single dose of LPS via i.p. injection and subsequently determined PTZinduced $(60 \mathrm{mg} / \mathrm{kg}$, i.p.) seizure susceptibility by scoring the severity and duration of the PTZ-induced seizure every $5 \mathrm{~min}$ for $2 \mathrm{~h}$ (Fig. 1a). The latency to initial seizure onset (clonic with/without tonic convulsion) after PTZ administration was significantly decreased in LPS-treated gp91 ${ }^{\text {phox-/- }}$ and $\mathrm{p} 47^{\text {phox-/- }}$ groups, compared with the LPS-treated WT group (Fig. 1b). In addition, the seizure susceptibility to PTZ of all three genotype groups treated with LPS was significantly increased, compared with the vehicle-treated (saline) control group (all $p$ values $<0.0001$ by two-way repeated-measures ANOVA). The main effect for LPS-treated WT, gp $91^{\text {phox-/- }}$, and $\mathrm{p} 47^{\text {phox-/- }}$ groups yielded an $\mathrm{F}$ ratio of $\mathrm{F}(2,432)=34.12, \quad p<0.0001$, indicating a significant difference between these three groups in susceptibility to PTZ-induced seizure. The Bonferroni test further revealed a significant difference between the WT group and gp91 $1^{\text {phox-l- }}(\mathrm{F}(1,288)=42.63$; $p<0.0001)$ and between WT and $\mathrm{p} 47^{\text {phox- }-}(\mathrm{F}(1,288)=$ 54.86; $p<0.0001)$, but no difference between $\mathrm{p} 47^{\text {phox-1- }}$ and gp91 ${ }^{\text {phox-l- }}$ groups $((\mathrm{F}(1,288)=1.16 ; p=0.282)$. The results indicate that both LPS-treated $\mathrm{gp} 91^{\text {phox-l- }}$ and $\mathrm{p} 47^{\text {phox }}$ groups exhibited significantly attenuated the increased seizure susceptibility, compared with the LPStreated WT group (Fig. 1c). We measured the duration of stage 4-6 seizures among the mice receiving LPS or vehicle control. The results showed that the seizure duration was $2.14 \pm 0.73$ (mean \pm SEM), $18.00 \pm 2.67,8.14 \pm 1.44$, and $8.43 \pm 1.36$ mins, for the vehicle-treated WT, LPStreated WT, LPS-treated gp91 $1^{\text {phox-/-}}$, and LPS-treated p4 $7^{\text {phox-l- }}$ groups, respectively (Fig. 1d). Notably, there was no difference between $\mathrm{gp} 91^{\text {phox-l- }}$ and $\mathrm{p} 47^{\text {phox-l- }}$ mice following LPS injection $(p>0.05)$. These results strongly suggested that NOX2 was a critical component of the elevation in seizure susceptibility following systemic inflammation.

\section{NOX2 deletion attenuated microglial activation and the upregulation of proconvulsive cytokines following LPS injection}

To further elucidate how systemic inflammation increased seizure susceptibility, we examined the effect of NOX2 knockout on inflammation in the peripheral and central nervous systems. Peripheral TNF $\alpha$ has been shown as an important mediator of seizure susceptibility following LPS-induced systemic inflammation [4]. a

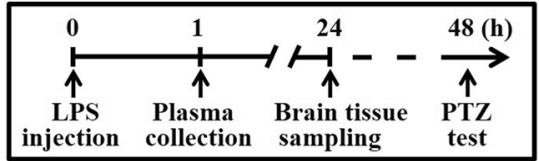

C

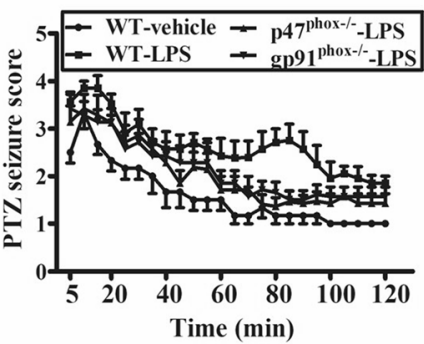

b



d



Fig. 1 NADPH oxidase deletion reduced the increased pentylenetetrazole (PTZ)-induced seizure susceptibility following lipopolysaccharide (LPS) stimulation. a The experiment protocol is schematized. Wild-type (WT), gp91 ${ }^{\text {phox-l--}}$, and p47 ${ }^{\text {phox }-1-}$ mice were injected intraperitoneally (i.p.) with 4 mg/kg lipopolysaccharide (LPS). Plasma samples were collected $1 \mathrm{~h}$ later for TNFa quantification and some mice were sacrificed $24 \mathrm{~h}$ later for the preparation of brain sections and transcript assays. Two days later, seizure susceptibility to $60 \mathrm{mg} / \mathrm{kg}$ PTZ (i.p.) was evaluated ( $n=6$ or 7 mice per genotype). b The latency to initial seizure onset (clonic with/without tonic convulsion) after PTZ administration. Data are presented as mean \pm SEM. Bonferroni post hoc test vs. LPStreated WT group; ${ }^{*} p<0.05,{ }^{* *} p<0.01$. c Seizure susceptibility of gp91 ${ }^{\text {phox }-/-}$, and p47 ${ }^{\text {phox-l- }}$ and WT mice scored once every 5 min over the $2-h$ period following PTZ injection. Two-way repeated measures ANOVA revealed that the main effect for LPS-treated WT, gp91 ${ }^{\text {phox- }- \text { - }}$, and p47 ${ }^{\text {phox- }-1-}$ groups yielded an $\mathrm{F}$ ratio of $\mathrm{F}(2,432)=34.12, p<0.0001$, Bonferroni post-test analysis further revealed significant difference between the WT group and gp91 ${ }^{\text {phox- } /-}$ $(F(1,288)=42.63 ; p<0.0001)$ and between WT and $4^{7^{\text {phox }-/-}}(F(1,288)=54.86 ; p<0.0001)$, but no difference between p47 ${ }^{\text {phox }-/-}$ and gp91 ${ }^{\text {phox }-/-}$ groups $((F(1,288)=1.16 ; p=0.282)$. $\mathbf{d}$ The total duration $(\mathrm{min})$ of seizure behavior $\geq$ stage 4 . Data are presented as mean \pm SEM. Bonferroni post hoc test vs. vehicle-treated or LPS-treated WT group; ${ }^{* *} p<0.01,{ }^{* * *} p<0.001$ 
Therefore, we first compared TNF $\alpha$ levels in the plasma collected from these WT, gp91 ${ }^{\text {phox-/- }}$, and $\mathrm{p} 47^{\text {phox-/- }}$ groups of mice $1 \mathrm{~h}$ after LPS or vehicle injection. Our data showed that there was no difference in the basal levels of TNF $\alpha$ among the groups and that LPS increased plasma TNF $\alpha$ levels in those three groups with indistinguishable potency (Fig. 2a). We also examined the basal levels of PTZ-seizure susceptibility, the microglial protein marker iba-1, the astrocytic marker glial fibrillary acidic protein (GFAP), and the brain-derived neurotrophic factor (BDNF), a marker related to neuronal excitability [36] in the brains of the wild-type and NOX2-knockout mice without LPS injection. We found no difference in the PTZ-induced seizure susceptibility, including latency to seizure onset and the duration of seizures (stage 4-6) between the WT and NOX2knockout mice (see Additional file 1). We also found no differences in the expression of these glial and neuronal markers among these groups (see Additional file 1). In addition, they had similar characteristics to those of resting microglia, composed of long branching processes and a small cellular body (see Additional file 1).
In response to systemic inflammation, microglia are rapidly activated and undergo morphological changes, consisting of the cell body increasing in size and becoming irregular in shape with thicker and shorter processes (Fig. 2b). Following LPS stimulation, the proportion of activated microglia was significantly lower in the brains (including the hippocampus) of gp91 $1^{\text {phox }}$ and $\mathrm{p} 47^{\text {phox }}$ knockout mice compared with WT mice (Fig. 2b,c). Next, we determined the levels of cytokines that have been shown as contributors to seizure occurrence, including TNF $\alpha$, IL-1 $\beta$, CCL2, IL-6, and IL-12, and the anti-inflammatory cytokine IL-10, which may protect against seizure activity. We measured the expression of these cytokines in the brains of the wild-type and NOX2-knockout mice $1.5 \mathrm{~h}$ after LPS injection. RTqPCR analyses showed that these six cytokines were significantly elevated in all genotypes, but the increases of TNF $\alpha$, IL-1 $\beta$, IL-6, and CCL2 were significantly attenuated, and the increase of IL-10 was enhanced in NOX2-knockout mice compared with WT mice (Fig. 3). Collectively, these data suggest that NOX2-dependent microglial activation and the ensuing production of
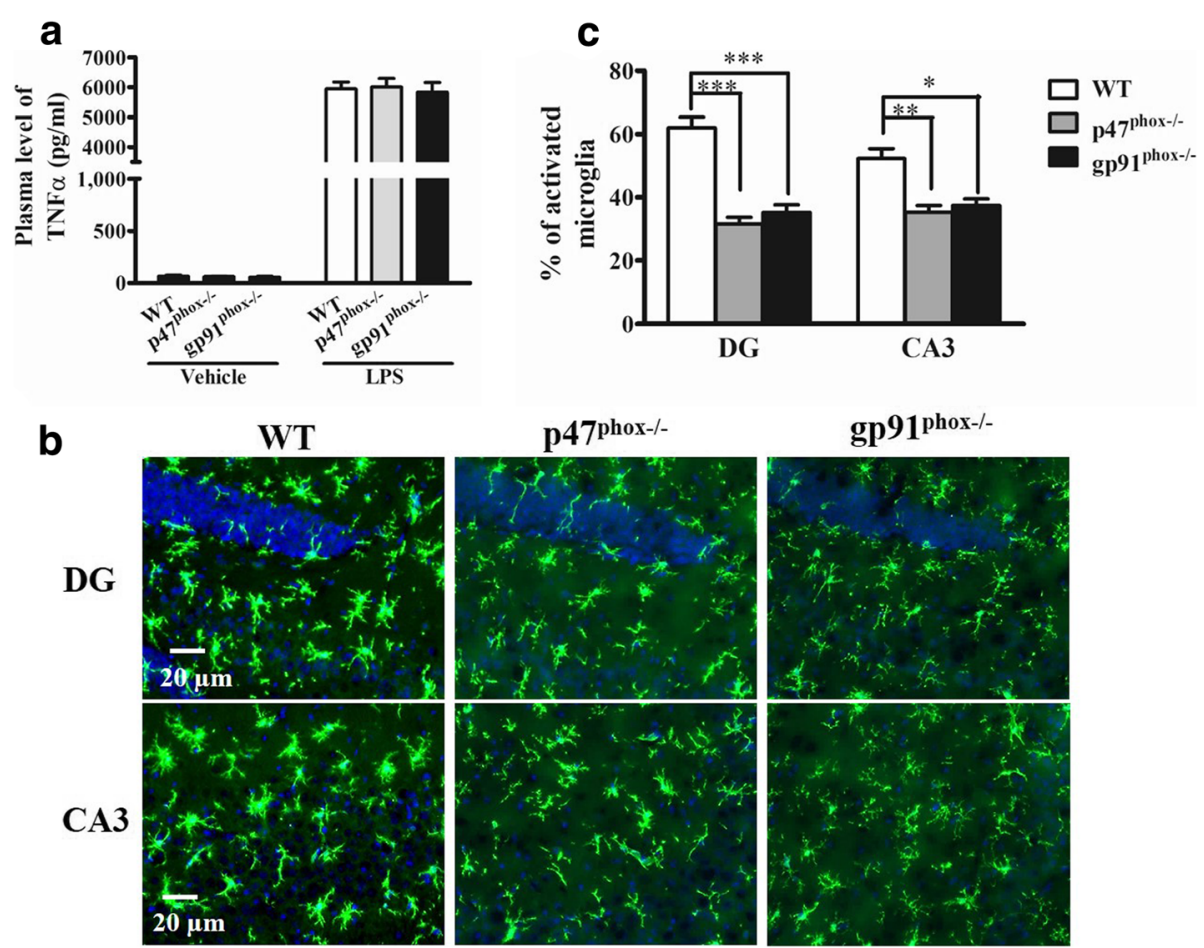

Fig. 2 Effects of NADPH oxidase subunit deletion on plasma TNFa levels and microglial activation after LPS injection. a The plasma TNFa levels were not affected by NOX2 subunit knockout (gP91 ${ }^{\text {phox- } /-}$ and P47 $7^{\text {phox-/-}}$ ) 1 h after LPS. Data are presented as mean \pm SEM; $n=5 / g r o u p$. Bonferroni post hoc test vs. vehicle-treated or LPS-treated wild-type (WT) group; $p>0.05$. b WT, gp9 $1^{\text {phox-l-}}$, and P47 ${ }^{\text {phox-l- }}$ mice were sacrificed $24 \mathrm{~h}$ after $4 \mathrm{mg} / \mathrm{kg}$ LPS injection (i.p.). Brain sections were immunostained for the microglial marker lba-1. Representative images of the stained microglia in the dentate gyrus (DG) and CA3 regions of mouse hippocampus ( $n=3$ mice per genotype) are shown. c Activated microglia were identified by increased cell size and irregular shape. The proportions of activated microglia in hippocampus were estimated. Data are mean \pm SEM of values from three animals per genotype. Bonferroni post hoc test vs. LPS-treated WT mouse group; ${ }^{*} p<0.05,{ }^{* *} p<0.01,{ }^{* *} p<0.001$ 

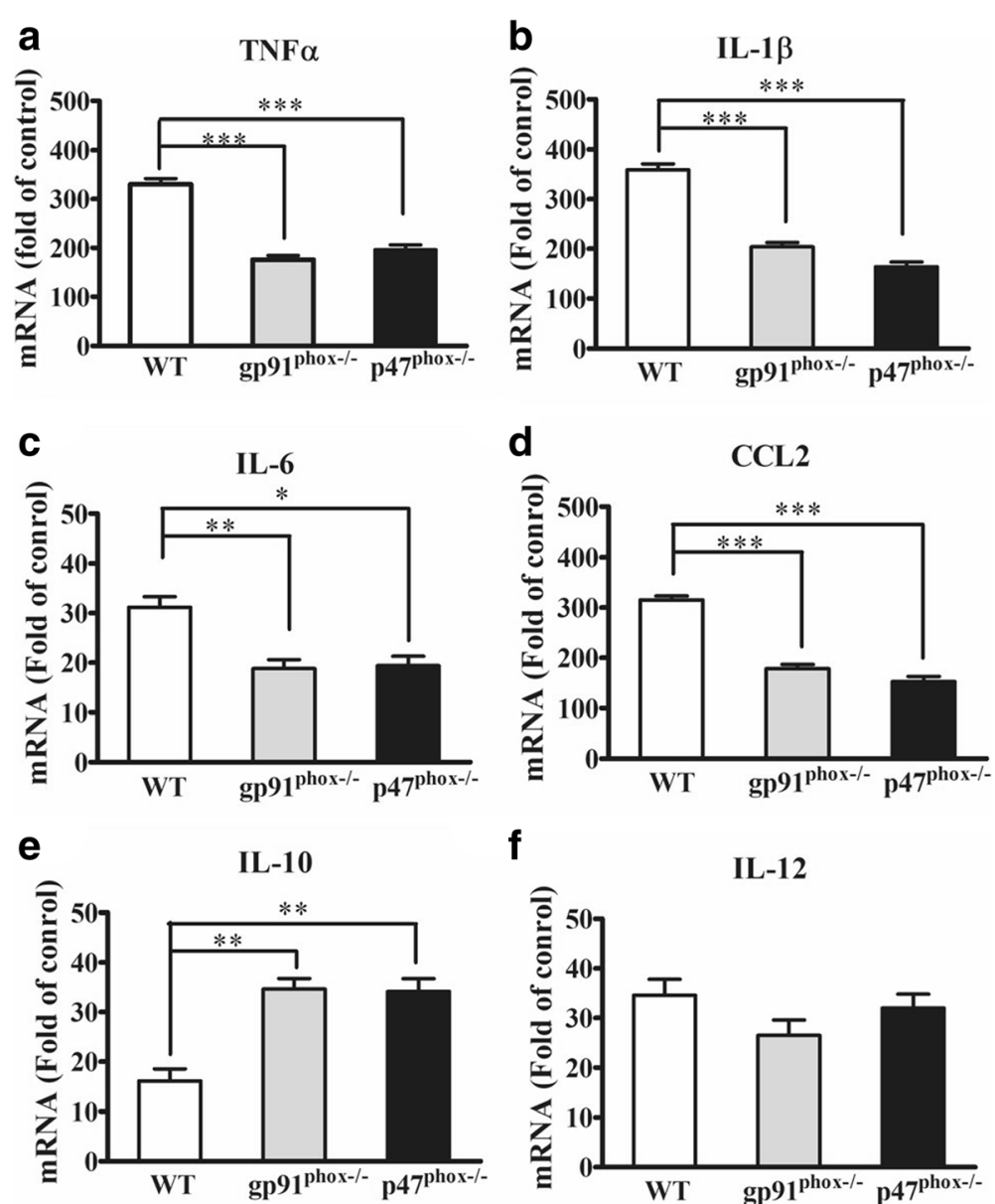

Fig. 3 NADPH oxidase deletion attenuated the upregulation of proconvulsive cytokines in mouse brain following LPS stimulation. Wild-type (WT), gp91 ${ }^{\text {phox- }-}$ and P47 ${ }^{\text {phox-l- }}$ mice were treated with saline (vehicle) or $4 \mathrm{mg} / \mathrm{kg}$ LPS (i.p.). Mouse brains ( $n=5$ per genotype) were harvested $1.5 \mathrm{~h}$ after LPS injection. The mRNA levels of TNFa, IL-13, CCL2, IL-6, IL-10, and IL-12 was determined by RT-qPCR (a-f). Cytokine mRNA expression was normalized to $\beta$-actin mRNA expression (internal control). Fold change was calculated by comparing the expression of each cytokine of the LPS-treated mice to that of the genotype-matched saline-treated mice. Data present the mean \pm SEM. Bonferroni post hoc test vs. corresponding WT control; ${ }^{*} p<0.05$, ${ }^{* *} p<0.01,{ }^{* * *} p<0.001$

proinflammatory cytokines play a key role in the systemic inflammation-elicited increase in seizure susceptibility.

\section{Primary cultured microglia from NOX2-deleted mice showed reduced proconvulsive factor expression after LPS, TNFa, and IL- $1 \beta$ stimulation}

In this scenario of systemic inflammation and ensuing neuroinflammation, many factors, including LPS and cytokines, may contribute to microglial activation, which in turn produce many proinflammatory factors [37, 38]. To investigate the role of microglial NOX2 in these events, we prepared primary enriched-microglial cultures from the WT and NOX2-knockout mice, and treated these cultures with $5 \mathrm{ng} / \mathrm{ml}$ LPS, $500 \mathrm{pg} / \mathrm{ml}$ TNF $\alpha$, or $500 \mathrm{pg} / \mathrm{ml} \mathrm{IL-1 \beta}$ for $1 \mathrm{~h}$. TNF $\alpha$ and IL- $1 \beta$ are two main important proconvulsive cytokines in the periphery and in the CNS following LPS administration
$[4,9,37]$. RT-qPCR analyses showed that LPS treatment significantly enhanced the expression of TNF $\alpha$, IL-1 $\beta$, and CCL2 in primary microglia from all three groups of mice, but the induction in NOX2-knockout microglia was approximately $50 \%$ lower than that in the WT (Fig. 4a). TNF $\alpha$ significantly enhanced levels of TNF $\alpha$, IL-1 $1 \beta$, and CCL2 transcripts, but the increased levels of TNF $\alpha$ and IL- $1 \beta$ were significantly attenuated in $\mathrm{p} 47^{\text {phox-/- }}$ and gp $^{91 \text { phox-l- }}$ microglia compared with those of WT microglia (Fig. 4b). Similarly, IL1 $\beta$ stimulation upregulated TNF $\alpha$ mRNA levels in all genotypes, but the levels were significantly lower in $\mathrm{p} 47^{\text {phox-/- }}$ and $\mathrm{gp}^{91 \text { phox-/- }}$ microglia than in WT microglia (Fig. 4c). These results suggested that following LPS (i.p.) stimulation, microglial NOX2 played a critical role in the local production of pro-convulsive cytokines such as TNF $\alpha$ and IL-1 $\beta$, which in turn enhanced neuronal excitability and seizure susceptibility. 


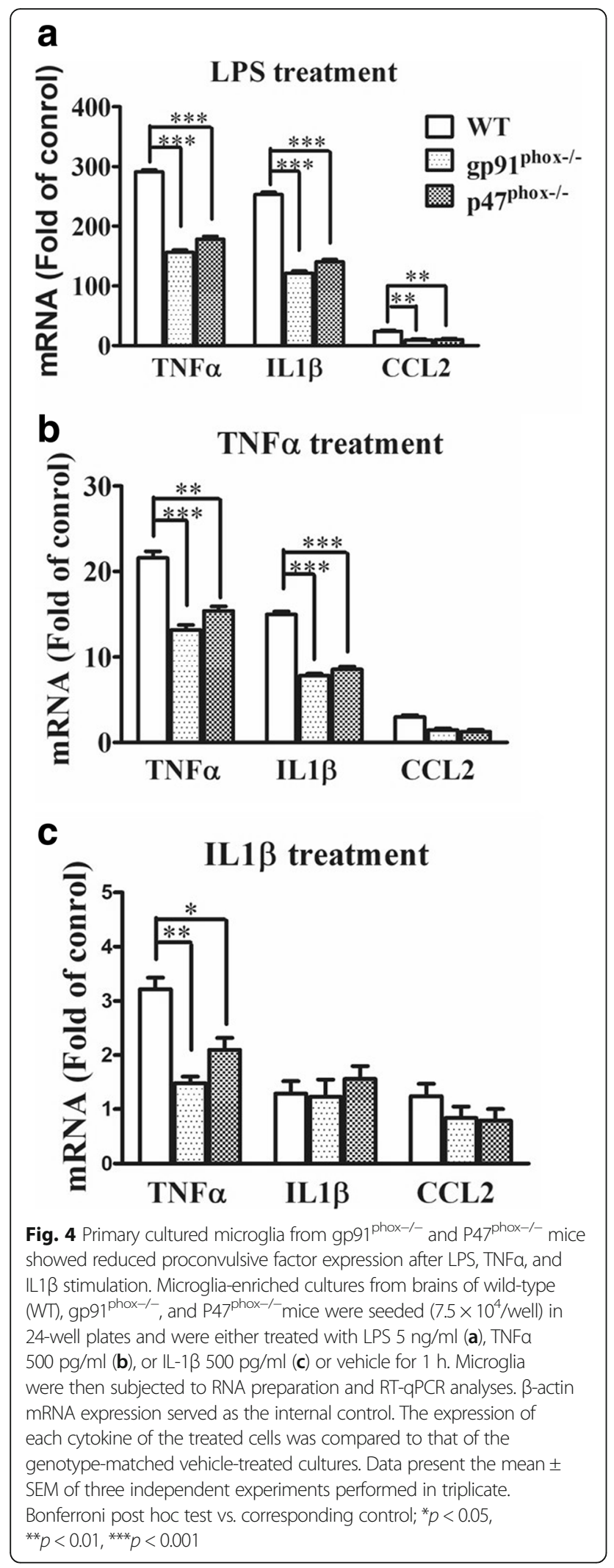

DPI post-treatment attenuated the increased seizure susceptibility following systemic inflammation

Based on the findings, we propose that NADPH oxidase is a potential pharmacological target to prevent the development of increased seizure susceptibility following systemic inflammation. We therefore investigated the anticonvulsant efficacy of the NADPH oxidase inhibitor DPI in the mouse sepsis model. Wild-type mice were treated with $0.01,0.1$, or $1 \mathrm{mg} / \mathrm{kg}$ (i.p.) DPI or vehicle (0.025\% DMSO) $30 \mathrm{~min}$ and $24 \mathrm{~h}$ after LPS administration, and blood samples were collected to measure plasma TNF $\alpha 1 \mathrm{~h}$ after LPS, and subsequently determined PTZ-induced (60 mg/kg, i.p.) seizure susceptibility (Fig. 5a). As shown in Fig. $5 \mathrm{~b}, 1 \mathrm{mg} / \mathrm{kg}$ of DPI significantly decreased plasma TNF $\alpha$ compared with vehicle treatment. The latency to initial seizure onset after PTZ administration was significantly increased in $1 \mathrm{mg} / \mathrm{kg}$ DPI-treated WT group, compared with vehicle-treated WT group $48 \mathrm{~h}$ after LPS injection (Fig. 5c). In addition, two-way repeated measures ANOVA revealed that the main effect for LPSinjected vehicle-treated and LPS-injected DPI-treated groups yielded an $\mathrm{F}$ ratio of $\mathrm{F}(3,576)=18.06, p<0.0001$, indicating a significant difference between these four groups to PTZ-induced seizure. Further analysis revealed that there is significant difference between the LPSinjected vehicle-treated group and LPS-injected $1 \mathrm{mg} / \mathrm{kg}$ DPI-treated group $(\mathrm{F}(1,288)=41.05 ; p<0.0001)$. The results indicate that $1 \mathrm{mg} / \mathrm{kg}$ DPI treatment significantly attenuated the PTZ-induced seizures susceptibility following LPS injection (Fig. 5d). The duration of PTZinduced seizure (stage 4-6) was also significantly decreased by $1 \mathrm{mg} / \mathrm{kg}$ DPI treatment (Bonferroni post hoc test; $p<0.01$ ) (Fig. 5e). These results indicated that DPI could attenuate peripheral TNF $\alpha$ levels as well as PTZ-induced seizure susceptibility in LPS-treated mice.

\section{DPI post-treatment attenuated microglia activation and pro-convulsive cytokine expression in brains after LPS injection}

Subsequent examinations of microglia morphology showed that post-treatment with DPI also decreased the proportion of activated microglia in the mouse CNS following systemic inflammation (Fig. 6a). While LPS induced an approximately 60 and 53\% increase of activated microglia in the DG and CA3 regions, respectively, DPI as low as $0.1 \mathrm{mg} / \mathrm{kg}$ was able to significantly attenuate microglia activation (Fig. 6b). Post-treatment with $1 \mathrm{mg} / \mathrm{kg}$ DPI significantly decreased the upregulation of TNF $\alpha$, IL-1 $\beta$, IL-6, and CCL2 mRNA in mouse brain $1.5 \mathrm{~h}$ after LPS treatment (Fig. $7 \mathrm{a}-\mathrm{d}$ ). The protein concentrations of these cytokines were measured in brain tissues $24 \mathrm{~h}$ after LPS injection using multiplex cytokine assays. DPI at $1 \mathrm{mg} / \mathrm{kg}$, but not at 0.01 or $0.1 \mathrm{mg} / \mathrm{kg}$, significantly 



Fig. 5 DPI post-treatment attenuated the increased seizure susceptibility following systemic inflammation. a The protocol for DPI post-treatment experiments is schematized. Wild-type (WT) mice were either injected intraperitoneally (i.p.) with $4 \mathrm{mg} / \mathrm{kg}$ LPS or with vehicle (saline). Then, the mice were treated with $0,0.01,0.1$, or $1 \mathrm{mg} / \mathrm{kg}$ DPI or vehicle (0.025\% DMSO) $30 \mathrm{~min}$ and $24 \mathrm{~h}$ after LPS injection. $48 \mathrm{~h}$ later, all the mice received PTZ ( $60 \mathrm{mg} / \mathrm{kg}$, i.p.) treatment ( $n=6$ or 7 mice/group). b Plasma samples were collected $1 \mathrm{~h}$ after LPS injection, and the levels of TNFa were determined and compared with that of the vehicle-treated mice. Data present the mean \pm SEM; $n=5$ for each treatment. Bonferroni post hoc test vs. LPS-vehicletreated group; ${ }^{*} p<0.05$. $\mathbf{c}$ The latency to initial seizure onset (clonic with/without tonic convulsion) after PTZ administration. Data are presented as mean \pm SEM. Bonferroni post hoc test vs. LPS-injected vehicle-treated group; ${ }^{* *} p<0.01$. d Seizure susceptibility scored once every 5 min for $2 \mathrm{~h}$ after PTZ injection. Two-way repeated measures ANOVA revealed that the main effect for LPS-injectee vehicle-treated and LPS-DPI-treated groups yielded an $\mathrm{F}$ ratio of $\mathrm{F}(3,576)=18.06, p<0.0001$. Bonferroni test analysis further revealed significant difference between the LPS-injected vehicle-treated group LPS-injected $1 \mathrm{mg} / \mathrm{kg}$ DPI-treated group $(F(1,288)=41.05 ; p<0.0001)$. e The total duration (min) of seizure behavior $\geq$ stage 4 . Data present the mean \pm SEM. Bonferroni post hoc $t$-test vs. LPS-injected vehicle treatment; ${ }^{*} p<0.05,{ }^{* *} p<0.01$

attenuated the upregulation of TNF $\alpha$, IL-1 $\beta$, IL- 6 , and CCL2 proteins compared with vehicle treatment (Fig. $7 \mathrm{e}-\mathrm{h}$ ), whereas $0.1 \mathrm{mg} / \mathrm{kg}$ DPI was also high enough to decrease IL-6 expression (Fig. 7g). However, there was no difference in the expression of IL-10 and IL-12 between vehicle-treated and DPI-treated mice following LPS injection (see Additional file 2). These results indicated that post-treatment with DPI could inhibit upregulation of proconvulsive cytokines (TNF $\alpha$, IL-1 $\beta$, IL-6, and CCL2) at both the mRNA and protein levels in mouse brain following systemic inflammation.
DPI post-treatment attenuated upregulation of gp91 in brain after LPS stimulation

We further examined whether DPI post-treatment affected NOX expression in mouse brain following LPS injection. RT-qPCR analyses showed that the expression of the gp91 transcript in brain was persistently upregulated for at least 1 day following LPS injection (Fig. 8a). We treated the mice with $0.01,0.1$, or $1 \mathrm{mg} / \mathrm{kg}$ DPI 30 min after LPS injection and harvested brains $24 \mathrm{~h}$ after LPS injection for RT-qPCR and western blot analyses. The data showed that DPI post-treatment dose- 


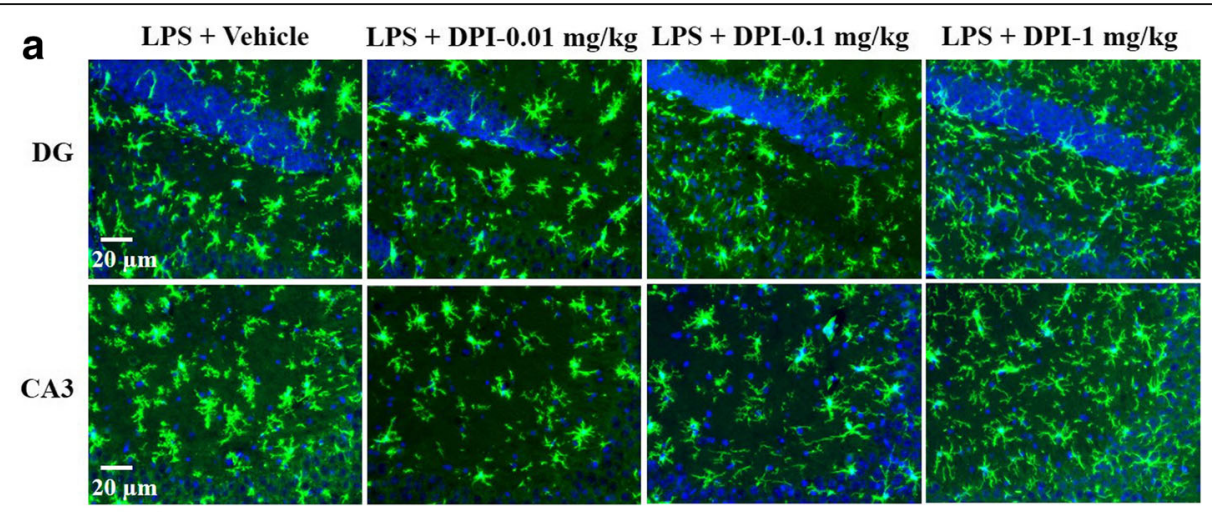

b

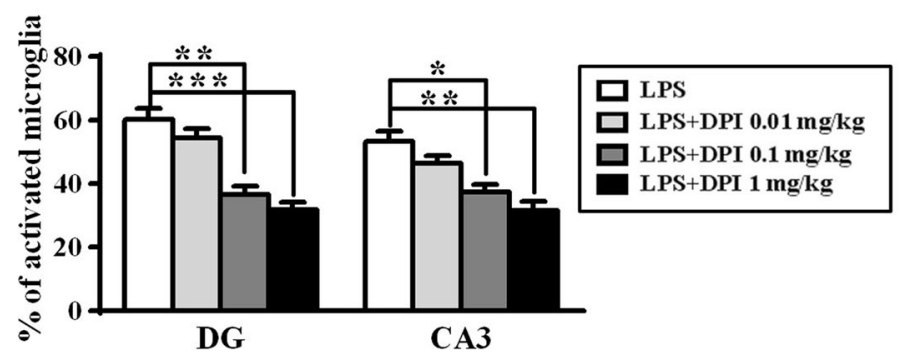

Fig. 6 DPI post-treatment attenuated microglia activation in brain after LPS injection. a Wild-type mice were treated with a single dose of 0.01, 0.1 , or $1 \mathrm{mg} / \mathrm{kg}$ DPI or vehicle (0.025\% DMSO) $30 \mathrm{~min}$ after $4 \mathrm{mg} / \mathrm{kg}$ LPS injection (i.p.), and then sacrificed $24 \mathrm{~h}$ after LPS. Brain sections were prepared and immunostained for the microglial marker iba-1. Representative images of the stained microglia in the dentate gyrus (DG) and CA3 regions of mouse hippocampus are shown. $\mathbf{b}$ Activated microglia were identified by increased cell size and irregular shape. The proportions of activated microglia in hippocampus were estimated. Data represent the mean \pm SEM of values from three animals per treatment. Bonferroni post hoc test vs. vehicle-treated mouse group; ${ }^{*} p<0.05,{ }^{* *} p<0.01,{ }^{* * *} p<0.001$

dependently reduced the expression of gp91 transcript (Fig. 8b) and gp91 protein (Fig. 8c,d). In comparison, NOX1 levels were not affected by DPI (see Additional file 3). These results further indicated that DPI post-treatment could also inhibit the deleterious neuroinflammatory response by attenuating the upregulation of NOX2 expression in the mouse brain following LPS stimulation.

\section{Discussion}

In the present study, we demonstrate that the increased seizure susceptibility following LPS-induced systemic inflammation strongly depends on activation of NOX2 in activated microglia. Our findings suggest that NOX2 activation and proinflammatory cytokine generation by microglia sustains the local neuroinflammatory response and increases neuronal excitability, which in turn reduces the threshold for seizure initiation, exacerbating seizure severity. Indeed, mice with NOX2 subunit knockout exhibited reduced microglial activation, attenuated production of the proconvulsive cytokines IL-1 $\beta$, TNF $\alpha$, IL-6, and CCL2, and lower seizure susceptibility to PTZ than wild-type mice following LPS-induced inflammation. Similarly, post-treatment with the NADPH oxidase inhibitor DPI following LPS also attenuated microglia activation and the expression of these proconvulsive cytokines in mouse brain. These results strongly suggest that like NOX2 deletion, DPI post-treatment suppresses sepsis-associated neuroinflammation and associated neuronal hyperexcitability, thereby reducing the probability of seizure induction.

The NOX family is comprised of seven members including NOX1-5 and DOUX1-2 [39]. Each isoform is composed of distinct NOX and regulatory subunits but all generate superoxide by transferring electrons across biological membranes. Both NOX1 and NOX2 are coexpressed in microglia but may have distinct functions in microglia activation $[40,41]$. In the present study, we clearly demonstrate that NOX2-derived ROS is critical for increasing seizure susceptibility following systemic inflammation via promotion of proconvulsive cytokine expression, although we cannot eliminate a contribution by NOX1. NOX2 is initially found in phagocytic cells (e.g., neutrophils) mediating host defense against microorganisms and also identified in non-phagocytic cells such as astroglia and neurons [42, 43]. NOX-derived ROS levels in non-phagocytic cells are typically much lower than in phagocytic cells since they are not generated to host defense, but as second messengers molecules in response to physiological stimuli (e.g., insulin) [44]. A study using LPS as a stimulus of microglial activation showed that only NOX2 from microglia, and not astrocytes and neurons, caused NADPH oxidase-mediated neuron damage 

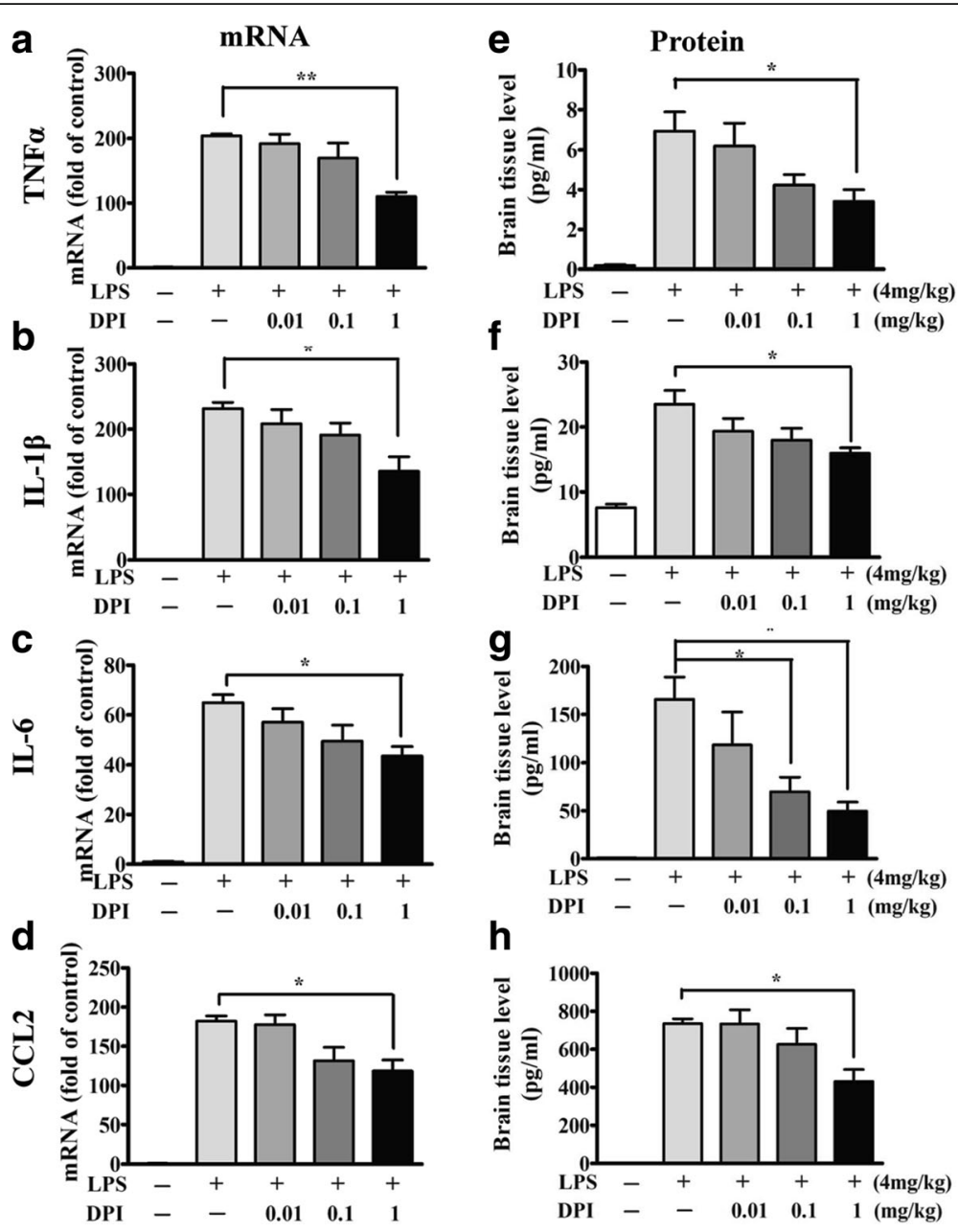

Fig. 7 DPI post-treatment attenuated pro-convulsive cytokine expression in brain after LPS injection. Wild-type mice were treated with a single dose of vehicle or DPI at $0.01,0.1$, or $1 \mathrm{mg} / \mathrm{kg} 30 \mathrm{~min}$ after LPS injection. The brains were harvested for assessment of the transcript expression

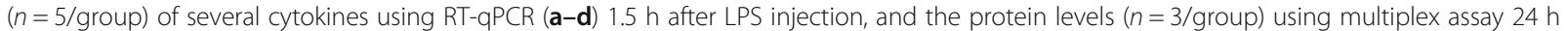
after LPS injection (e-h), respectively. $\beta$-actin expression served as the internal control. The expression of each cytokine of the DPI-treated mice was compared with that of the LPS-injected vehicle-treated control. Data present the mean \pm SEM. Bonferroni post hoc test vs. LPS-injected vehicle-treated group; ${ }^{*} p<0.05,{ }^{* *} p<0.01$

[42]. Another study also showed that immunoreactivity to gp91 ${ }^{\text {phox }}$ (NOX2 catalytic subunit) was mainly co-localized to activated microglia but co-localized to a few astrocytes and neurons in traumatic brain injury [43]. These studies suggest that even though NADPH oxidase can be activated in cells from the non-myeloid lineage, the resulting production of ROS is significantly lower than in microglia and in innate immunity (e.g., macrophages and neutrophils). Thus, microglia are likely the predominant source of NOX2-derived ROS in brain and thus a more effective target for prevention of neuronal hyperexcitability and seizure induction following sepsis.

Accumulating evidence indicates that systemic inflammation is accompanied by a similar inflammatory response in the CNS resulting from microglial activation and local synthesis of proinflammatory cytokines $[4,6$,
15, 45]. Although the precise mechanisms responsible for the initial synthesis of cytokines in the brain are not entirely clear, peripheral TNF $\alpha$ may be a critical trigger by promoting leukocyte-endothelial interactions, microglial activation, and subsequent recruitment of monocytes [46]. We found that greater plasma TNF $\alpha$ concentrations (induced by higher LPS doses, i.e., $4 \mathrm{mg} / \mathrm{kg}$ vs. $0.5 \mathrm{mg} / \mathrm{kg}$ i.p.) evoked more severe neuroinflammation through enhanced brain accumulation of proinflammatory factors such as TNF $\alpha$, IL-6, and IL-1 $\beta$ (see Additional file 4). Interestingly, LPS-induced plasma TNF $\alpha$ levels did not differ among gp91 ${ }^{\text {phox-/- }}, \mathrm{p} 47^{\text {phox-/- }}$, and WT mice, either in the current study (Fig. 2a) or in a previous study [47]. However, post-treatment with higher doses of DPI decreased plasma TNF $\alpha$ concentrations in mice following LPS stimulation. One possibility is that DPI, which is a 

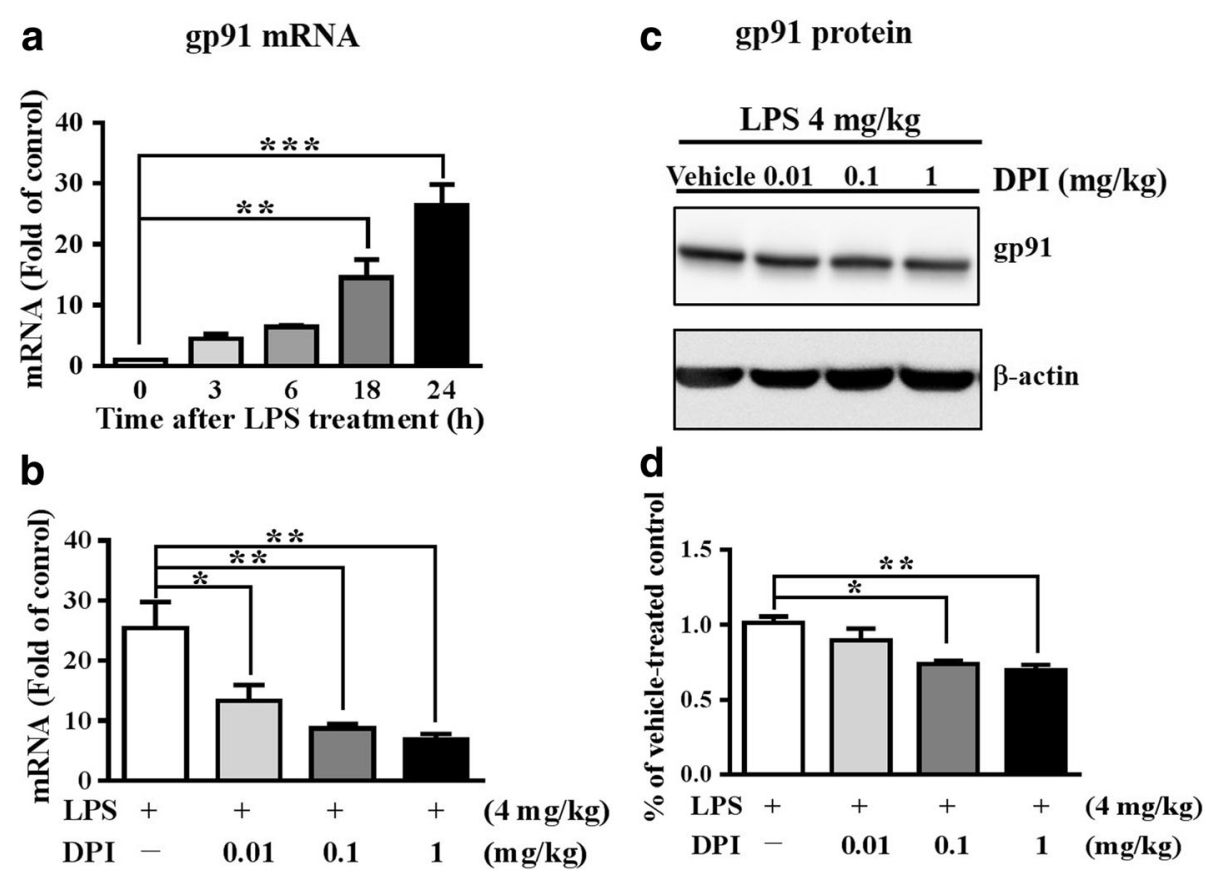

Fig. 8 DPI post-treatment attenuated gp91 expression in brain after LPS stimulation in mice. a Wild-type mice $(n=3 /$ group) were treated with LPS and were sacrificed $0,3,6,18$, and $24 \mathrm{~h}$ after LPS and the brains were harvested. The transcript levels of gp91 were determined by RT-qPCR analyses and compared with that of the vehicle-treated control (to which a value of 1 was assigned). Data present the mean \pm SEM. Bonferroni post hoc test vs. LPS-injected vehicle-treated group; ${ }^{* *} p<0.01,{ }^{* *} p<0.001$. b The mice were treated with a single dose of vehicle or DPI $(0.01$, 0.1 , or $1 \mathrm{mg} / \mathrm{kg}$ ) $30 \mathrm{~min}$ after LPS injection and then were sacrificed $24 \mathrm{~h}$ after LPS. The transcript levels of gp91 were determined by RT-qPCR analyses and compared with that of the LPS-injected vehicle-treated control (to which a value of 1 was assigned). Data present the mean \pm SEM. Bonferroni post hoc test vs. LPS-injected vehicle-treated group; ${ }^{*} p<0.05$, ${ }^{* *} p<0.01$. $\mathbf{c}$ The brains as described in $\mathbf{b}$ were analyzed by western blot analyses to determine the levels of gp91 protein. Representative blots are shown. $\mathbf{d}$ The gp91 signals were quantitated and normalized to the internal control. All the normalized values were compared to the LPS-injected vehicle-treated group (to which a value of 1 was assigned). Data represent the mean \pm SEM of the results generated from three animals for each group. Bonferroni post hoc test vs. LPS-injected vehicle-treated group; ${ }^{*} p<0.05,{ }^{* *} p<0.01$

general flavoprotein inhibitor, blocks other NOX isoforms as well as xanthine oxidase [48, 49]. Although it remains unclear whether genetic deletion of NOX2 subunits and DPI administration have distinct effects on other NOX enzymes (e.g., through compensatory changes in NOX isoform expression and non-selective pharmacological inhibition), our results suggest that DPI has additional protective benefits against neuroinflammation by inhibiting the production of peripheral inflammatory factors (e.g., TNF $\alpha$ ).

There is compelling evidence that proinflammatory cytokines can induce neuronal hyperexcitability and thus contribute to the development of epilepsy [7, 15]. It is believed that these effects are mediated by direct and indirect upregulation of excitatory glutamatergic transmission and downregulation of inhibitory GABAergic transmission $[50,51]$. NOX2 is one of the major sources of ROS for cellular signaling. The present study demonstrates that both genetic deletion of NOX2 subunits and DPI post-treatment can strongly inhibit proconvulsive cytokine gene expression in response to systemic inflammation (Figs. 3 and 7) and that microglia are a major source of these cytokines (Fig. 4). In addition, DPI attenuated NOX2 upregulation following sepsis (Fig. 8b, c), but had no effect on NOX1 expression (Additional file 3). These results support the hypothesis that DPI attenuates neuronal hyperexcitability by inhibiting NOX2 overexpression and NOX2-derived ROS signaling pathways linked to proconvulsive cytokine release.

Given the potential role of proconvulsive cytokines in mediating neuronal hyperexcitability following systemic inflammation, targeting these factors is considered a potential therapeutic strategy for suppressing the development of post-sepsis epilepsy [7, 52]. Moreover, targeting the early stages of neuroinflammation following systemic inflammation may prevent both inflammation- and seizureassociated brain damage due to oxidative stress and excitotoxicity. Based on the underlying molecular mechanism of these proconvulsive cytokines and their signaling pathways, several new immunotherapeutic approaches such as IL-1 $\beta$ converting enzyme inhibitors and suppression of NF-kB are currently in the experimental phase of development for drug-resistant epilepsy [52-54]. However, it still has not been established whether a single proconvulsive cytokine inhibitor such as a TNF $\alpha$ blocker is sufficient to prevent 
neuroinflammation-mediated neuronal hyperexcitability. In fact, following sepsis, multiple cytotoxic factors such as cytokines/chemokines, ROS, and NOS are released by activated microglia and can both damage neurons directly and induce hyperexcitability. Consequently, a self-sustaining cycle is created through interactions between damaged neurons and dysregulated microglia, which may eventually result in chronic neuroinflammation, epilepsy development, and progressive neurodegeneration $[6,7,55]$. NOX2 complexes that drive ROS signaling pathways are essential mediators of this process [24]. It is thus reasonable to speculate that inhibiting NADPH oxidases can reduce the accumulation of neurotoxic factors (e.g., cytokines, and ROS) and disrupt the development of this vicious pathogenic cycle $[24,55]$. Our findings indicated that NOX2 subunit deletion and pharmacological NOX2 inhibition reduced the upregulation of a broad spectrum of proconvulsive cytokines following LPS injection and attenuated subsequent increased seizure susceptibility.

A few studies have examined the therapeutic potential of preventing neuronal hyperexcitability associated with neuroinflammation. Hernandes and colleagues reported that pretreatment with the NOX2 inhibitor apocynin was effective in preventing the development of long-term cognitive impairment from sepsis-associated neuroinflammation [56]. Suppression of COX2-mediated inflammation is also a potential strategy for reducing neuronal hyperexcitability since COX-2 mRNA expression and PGE2 production are widely induced in rodent brain following sepsis [57]. In fact, a COX-2 inhibitor ameliorated the increase in KA-induced seizure susceptibility following sepsis via inhibition of NOX2 signaling [57, 58]. Wang and colleagues reported that post-treatment with ultra-low doses of DPI $(10 \mathrm{ng} / \mathrm{kg} / \mathrm{day})$ for 2 weeks prevented dopaminergic neurodegeneration and motor deficits in Parkinson's disease models through inhibition of chronic neuroinflammation [59]. In the present study, a single dose of $0.01 \mathrm{mg} / \mathrm{kg}$ DPI significantly reduced the expression of proconvulsive cytokine mRNA and gp91 ${ }^{\text {phox }}$ mRNA within $24 \mathrm{~h}$ after LPS injection, but only higher doses $(1 \mathrm{mg} / \mathrm{kg})$ attenuated seizure susceptibility. Collectively, these findings suggest that pharmacological NOX2 inhibitors may suppress the sepsis-associated increase in seizure susceptibility and resulting neurodegeneration by preventing microglial activation and downstream neuroinflammatory signaling.

\section{Conclusions}

In conclusion, this study shows that NOX2 contributes to neuronal hyperexcitability and increased seizure susceptibility in the LPS animal model of sepsis. Our data strongly suggest that pharmacological inhibition of NOX2-derived ROS may be an effective strategy to prevent sepsis-associated neuroinflammation, neuronal hyperexcitability, and seizures.

\section{Additional file}

\begin{abstract}
Additional file 1: Basal seizure susceptibility, molecular levels of cell populations, and morphology of microglia in wild-type and NADPHoxidase knockout mice. (A) The latency to initial seizure onset (clonic with/without tonic convulsion) after PTZ administration. Data are presented as mean \pm SEM. Bonferroni post hoc test vs. LPS-treated WT group $p>0.05$. (B) Basal seizure susceptibility scored once every 5 min over the 2-h period to $60 \mathrm{mg} / \mathrm{kg}$ PTZ (i.p.) in wild-type (WT), gp91 ${ }^{\text {phox-/- }}$, and P47 phox-/- mice ( $n=6$ or 7 per genotype). (C) The total duration (min) of seizure behavior $\geq$ stage 4 in gp9 $1^{\text {phox }-1-}$, P47 phox $-1-$, and WT mice. Data represent the mean \pm SEM. Bonferroni post hoc test vs. WT mouse group. (D) Representative immunoblots showing the basal protein levels of Iba-1 (microglia marker), GFAP (astroglia marker), and BDNF (neuronal marker) in brains of WT, gp91 ${ }^{\text {phox- }--}$ and P47 ${ }^{\text {phox-l- }}$ mice ( $n=3$ per genotype). Bonferroni post hoc test vs. WT mouse group. (E) Photomicrograph of iba1-staining microglia from the dentate gyrus regions (DG) and CA3 regions of each genotype mice ( $n=3$ per genotype). Resting microglia are composed of a small cellular body and long branching processes (arrow). (TIF $15422 \mathrm{~kb}$ )
\end{abstract}

Additional file 2: DPI post-treatment had no effect to attenuate IL10on attenuating IL-10 and IL-12 expression in brain after LPS injection. Wild-type mice were treated with a single dose of vehicle or DPI at 0.01, 0.1, or $1 \mathrm{mg} / \mathrm{kg} 30 \mathrm{~min}$ after LPS injection. At 1.5 and $24 \mathrm{~h}$ after LPS injection, mice were sacrificed and brain extracts prepared for analysis of cytokine transcript ( $n=5$ /group) and protein expression ( $n=3$ /group) by real-time PCR and multiplex assay, respectively. The transcript levels of $\mathrm{IL}-10(\mathrm{~A})$, and $\mathrm{IL}-12$ (B) at $1.5 \mathrm{~h}$ after LPS injection. Data are presented as mean \pm SEM. Bonferroni post hoc test vs. LPS-injected vehicle-treated group, $p>0.05$. The protein levels of IL-10 (C), and IL-12 (D) in brain at $24 \mathrm{~h}$ after LPS injection. Values are presented as mean \pm SEM. Bonferroni post hoc test vs. LPS-injected vehicle-treated control. (TIF $13787 \mathrm{~kb}$ )

Additional file 3: DPI post-treatment after LPS stimulation had no significant effect on NOX1 expression. C57BL/6 mice were treated with a single dose of vehicle or DPI 30 min after LPS injection (4 mg/kg; i.p.) and sacrificed $24 \mathrm{~h}$ after LPS injection. Representative immunoblots showing the levels of NADPH oxidase 1 (NOX1) protein in vehicle- or DPI-treated mouse brain are shown (A). Quantitative analysis indicated that NOX1 protein expression was not significantly changed by DPI post-treatment (B). Data represent the mean \pm SEM of three animals per treatment group. Bonferroni post hoc test vs. LPS-injected vehicle-treated group; $p>0.05$. (TIF $8723 \mathrm{~kb}$ )

Additional file 4: Dose response of LPS on plasma TNFa levels and cytokine gene expression in mouse brain. Male C57BL/6J mice were treated with a lower dose $(0.5 \mathrm{mg} / \mathrm{kg})$ or a higher dose $(4 \mathrm{mg} / \mathrm{kg})$ of LPS. (A) Plasma levels of TNF-a $1 \mathrm{~h}$ after LPS stimulation. Student's $t$-test; $n=5 /$ group; ${ }^{* * *} p<0.001$. (B) The levels of TNFa, IL-1 $\beta$, and IL-6 transcripts in brain $1.5 \mathrm{~h}$ after LPS stimulation ( $n=3$ /group). The mRNA levels were calculated relative to expression in matched saline-treated mice. $\beta$-actin mRNA was the internal control. Data present the mean \pm SEM. Student's t-test; ${ }^{* * *} p<0.001$. (TIF $10736 \mathrm{~kb})$

\section{Abbreviations}

BDNF: Brain-derived neurotrophic factor; CCL2: C-C motif chemokine ligand 2; DPI: Diphenyleneiodonium; GFAP: Glial fibrillary acidic protein; Iba-1: Ionized calcium binding adaptor molecule 1; IL-12: Interleukin 12; IL-1 $\beta$ : Interleukin 1 $\beta$; IL-6: Interleukin 6; LPS: Lipopolysaccharide; NOX2: NADPH oxidase 2; PTZ: Pentylenetetrazol; ROS: Reactive oxygen species; TNFa: Tumor necrosis factor-alpha

\section{Acknowledgements}

We thank Chew-Teng Kor PhD. Department of Internal Medicine, Changhua Christian Hospital for her valuable help in data analysis.

\section{Funding}

The study was funded by grant NSC100-2314-B-371-004 and NSC 101-2314B-371-006-MY3 from Ministry of Science and Technology, Taiwan. 


\section{Availability of data and materials}

The datasets supporting the conclusions of this article are included within the article and its Additional files. All material used in this manuscript will be made available to researchers subject to confidentiality.

\section{Authors' contributions}

SL, HYX, TYC, and YPC performed the experiments. HMW and KSH designed the study, and WYH analyzed the data and wrote the manuscript. All authors read and approved the final manuscript.

\section{Ethics approval}

The experiments were approved by the Animal Care and Use Committee of Changhua Christian Hospital, and the experiments were performed according to the Guide for the Care and Use of Laboratory Animals of the National Institutes of Health of the United States.

\section{Competing interests}

The authors declare that they have no competing interests.

\section{Publisher's Note}

Springer Nature remains neutral with regard to jurisdictional claims in published maps and institutional affiliations.

\section{Author details}

${ }^{1}$ Institute of Basic Medical Sciences, College of Medicine, National Cheng Kung University, Tainan, Taiwan. ${ }^{2}$ Pediatrics of Kung-Ten General Hospital, Taichung City, Taiwan. ${ }^{3}$ Inflammation Research \& Drug Development Center, Changhua Christian Hospital, Changhua, Taiwan. ${ }^{4}$ Department of Neurology, Changhua Christian Hospital, Changhua City, Taiwan. ${ }^{5}$ Institute of Acupuncture, School of Chinese Medicine, China Medical University, Taichung City, Taiwan.

\section{Received: 19 February 2018 Accepted: 2 May 2018}

Published online: 12 May 2018

\section{References}

1. Sonneville R, Verdonk F, Rauturier C, Klein IF, Wolff M, Annane D, et al. Understanding brain dysfunction in sepsis. Ann Intensive Care. 2013;3:15.

2. Idro R, Gwer S, Kahindi M, Gatakaa H, Kazungu T, Ndiritu M, et al. The incidence, aetiology and outcome of acute seizures in children admitted to a rural Kenyan district hospital. BMC Pediatr. 2008;8:5

3. Riazi K, Galic MA, Pittman QJ. Contributions of peripheral inflammation to seizure susceptibility: cytokines and brain excitability. Epilepsy Res. 2010;89: 34-42.

4. Riazi K, Galic MA, Kuzmiski JB, Ho W, Sharkey KA, Pittman QJ. Microglial activation and TNFalpha production mediate altered CNS excitability following peripheral inflammation. Proc Natl Acad Sci U S A. 2008:105: 17151-6.

5. Cerri C, Genovesi S, Allegra M, Pistillo F, Puntener U, Guglielmotti A, et al. The chemokine CCL2 mediates the seizure-enhancing effects of systemic inflammation. J Neurosci. 2016;36:3777-88.

6. Qin L, Wu X, Block ML, Liu Y, Breese GR, Hong JS, et al. Systemic LPS causes chronic neuroinflammation and progressive neurodegeneration. Glia. 2007; 55:453-62.

7. Galic MA, Riazi K, Heida JG, Mouihate A, Fournier NM, Spencer SJ, et al. Postnatal inflammation increases seizure susceptibility in adult rats. J Neurosci. 2008;28:6904-13.

8. Harre EM, Galic MA, Mouihate A, Noorbakhsh F, Pittman QJ. Neonatal inflammation produces selective behavioural deficits and alters N-methyl-Daspartate receptor subunit mRNA in the adult rat brain. Eur J Neurosci. 2008;27:644-53.

9. Skelly DT, Hennessy E, Dansereau MA, Cunningham C. A systematic analysis of the peripheral and CNS effects of systemic LPS, IL-1beta, TNF-alpha and IL-6 challenges in C57BL/6 mice. PLoS One. 2013;8:e69123.

10. Erickson MA, Banks WA. Cytokine and chemokine responses in serum and brain after single and repeated injections of lipopolysaccharide: multiplex quantification with path analysis. Brain Behav Immun. 2011:25:1637-48.

11. Eklind S, Mallard C, Arvidsson P, Hagberg H. Lipopolysaccharide induces both a primary and a secondary phase of sensitization in the developing rat brain. Pediatr Res. 2005;58:112-6.
12. Hagberg $H$, Mallard $C$. Effect of inflammation on central nervous system development and vulnerability. Curr Opin Neurol. 2005;18:117-23.

13. Godbout JP, Johnson RW. Age and neuroinflammation: a lifetime of psychoneuroimmune consequences. Imunol Allergy Clin North Am. 2006; 24:521-38.

14. Pascual O, Ben Achour S, Rostaing P, Triller A, Bessis A. Microglia activation triggers astrocyte-mediated modulation of excitatory neurotransmission. Proc Natl Acad Sci U S A. 2012;109:197-205.

15. Galic MA, Riazi K, Pittman QJ. Cytokines and brain excitability. Front Neuroendocrinol. 2012;33:116-25.

16. Heida JG, Pittman QJ. Causal links between brain cytokines and experimental febrile convulsions in the rat. Epilepsia. 2005:46:1906-13.

17. Rodgers KM, Hutchinson MR, Northcutt A, Maier SF, Watkins LR, Barth DS. The cortical innate immune response increases local neuronal excitability leading to seizures. Brain. 2009:132:2478-86.

18. Vezzani A, Moneta D, Richichi C, Aliprandi M, Burrows SJ, Ravizza T, et al. Functional role of inflammatory cytokines and antiinflammatory molecules in seizures and epileptogenesis. Epilepsia. 2002;43(s5):30-5.

19. Gruol DL. IL-6 regulation of synaptic function in the CNS. Neuropharmacology. 2015;96:42-54.

20. Vezzani A, Ravizza T, Balosso S, Aronica E. Glia as a source of cytokines: implications for neuronal excitability and survival. Epilepsia. 2008; 49(s2):24-32.

21. Li G, Bauer S, Nowak M, Norwood B, Tackenberg B, Rosenow F, et al. Cytokines and epilepsy. Seizure. 2011;20:249-56.

22. Wilkinson BL, Landreth GE. The microglial NADPH oxidase complex as a source of oxidative stress in Alzheimer's disease. J Neuroinflammation. 2006:3:30.

23. Block ML, Zecca L, Hong JS. Microglia-mediated neurotoxicity: uncovering the molecular mechanisms. Nat Rev Neurosci. 2007:8:57-69.

24. Vezzani A, French J, Bartfai T, Baram TZ. The role of inflammation in epilepsy. Nat Rev Neurol. 2011;7:31-40.

25. Iori V, Frigerio F, Vezzani A. Modulation of neuronal excitability by immune mediators in epilepsy. Curr Opin Pharmacol. 2016;26:118-23.

26. Somera-Molina KC, Robin B, Somera CA, Anderson C, Stine C, Koh S, et al. Glial activation links early-life seizures and long-term neurologic dysfunction: evidence using a small molecule inhibitor of proinflammatory cytokine upregulation. Epilepsia. 2007;48:1785-800.

27. Doussiere J, Gaillard J, Vignais PV. The heme component of the neutrophil NADPH oxidase complex is a target for aryliodonium compounds. Biochemistry. 1999;38:3694-703.

28. Qian L, Wu HM, Chen SH, Zhang D, Ali SF, Peterson L, et al. ß2-adrenergic receptor activation prevents rodent dopaminergic neurotoxicity by inhibiting microglia via a novel signaling pathway. J Immunol. 2011;186:4443-54.

29. Dhir A. Pentylenetetrazol (PTZ) kindling model of epilepsy. Curr Protoc Neurosci. 2012;9:9-37.

30. Corda MG, Orlandi M, Lecca D, Carboni G, Frau V, Giorgi O. Pentylenetetrazol-induced kindling in rats: effect of GABA function inhibitors. Pharmacol Biochem Behav. 1991;40:329-33.

31. Liu H, Cao Y, Basbaum Al, Mazarati AM, Sankar R, Wasterlain CG. Resistance to excitotoxin-induced seizures and neuronal death in mice lacking the preprotachykinin A gene. Proc Natl Acad Sci U S A. 1999;96:12096-101.

32. Morrison RS, Wenzel HJ, Kinoshita Y, Robbins CA, Donehower LA, Schwartzkroin PA. Loss of the p53 tumor suppressor gene protects neurons from kainate-induced cell death. J Neurosci. 1996;16:1337-45.

33. Wu HM, Tzeng NS, Qian L, Wei SJ, Hu X, Chen SH, et al. Novel neuroprotective mechanisms of memantine: increase in neurotrophic factor release from astroglia and anti-inflammation by preventing microglial activation. Neuropsychopharmacology. 2009;34:2344-57.

34. Fox C, Dingman A, Derugin N, Wendland MF, Manabat C, Ji S, et al. Minocycline confers early but transient protection in the immature brain following focal cerebral ischemia-reperfusion. J Cereb Blood Flow Metab. 2005;25:1138-49.

35. Mirrione MM, Konomos DK, Gravanis I, Dewey SL, Aguzzi A, Heppner FL, et al. Microglial ablation and lipopolysaccharide preconditioning affects pilocarpine-induced seizures in mice. Neurobiol Dis. 2010;39:85-97.

36. Binder DK, Croll SD, Gall CM, Scharfman HE. BDNF and epilepsy: too much of a good thing? Trends Neurosci. 2001;24:47-53.

37. Thomson CA, McColl A, Cavanagh J, Graham GJ. Peripheral inflammation is associated with remote global gene expression changes in the brain. J Neuroinflammation. 2014;11:73. 
38. Hanisch UK. Microglia as a source and target of cytokines. Glia. 2002;40:140-55.

39. Bedard K, Krause KH. The NOX family of ROS-generating NADPH oxidases: physiology and pathophysiology. Physiol Rev. 2007;87:245-313.

40. Brown DI, Griendling KK. Nox proteins in signal transduction. Free Radic Bio Med. 2009;47:1239-53.

41. Chéret C, Gervais A, Lelli A, Colin C, Amar L, Ravassard P, Mallet J, Cumano A, Krause $\mathrm{KH}$, Mallat M. Neurotoxic activation of microglia is promoted by a nox1-dependent NADPH oxidase. J Neurosci. 2008;28:12039-51.

42. Qin L, Liu Y, Wang T, Wei SJ, Block ML, Wilson B, et al. NADPH oxidase mediates lipopolysaccharide-induced neurotoxicity and proinflammatory gene expression in activated microglia. J Biol Chem. 2004;279:1415-21.

43. Dohi K, Ohtaki H, Nakamachi T, Yofu S, Satoh K, Miyamoto K, et al. Gp91 phox (NOX2) in classically activated microglia exacerbates traumatic brain injury. J Neuroinflammation. 2010;7:41.

44. Angeloni C, Prata C, Dalla Sega FV, Piperno R, Hrelia S. Traumatic brain injury and NADPH oxidase: a deep relationship. Oxid Med Cell Longev. 2015;2015:370312. https://doi.org/10.1155/2015/370312.

45. Pyter LM, Pineros V, Galang JA, McClintock MK, Prendergast BJ. Peripheral tumors induce depressive-like behaviors and cytokine production and alter hypothalamic-pituitary-adrenal axis regulation. Proc Natl Acad Sci U S A. 2009;106:9069-74.

46. D'Mello C, Le T, Swain MG. Cerebral microglia recruit monocytes into the brain in response to tumor necrosis factoralpha signaling during peripheral organ inflammation. J Neurosci. 2009;29:2089-102.

47. Zhang WJ, Wei H, Frei B. Genetic deficiency of NADPH oxidase does not diminish, but rather enhances, LPS-induced acute inflammatory responses in vivo. Free Radic Biol Med. 2009:46:791-8.

48. Maraldi T. Natural compounds as modulators of NADPH oxidases. Oxidative Med Cell Longev. 2013;2013:271602.

49. Wind $\mathrm{S}$, Beuerlein $\mathrm{K}$, Eucker T, Müller $\mathrm{H}$, Scheurer $\mathrm{P}$, Armitage $\mathrm{ME}$, et al. Comparative pharmacology of chemically distinct NADPH oxidase inhibitors. Br J Pharmacol. 2010;161:885-98.

50. Zhou Y, Tang H, Liu J, Dong J, Xiong H. Chemokine CCL2 modulation of neuronal excitability and synaptic transmission in rat hippocampal slices. J Neurochem. 2011;116:406-14.

51. Zhu G, Okada M, Yoshida S, Mori F, Ueno S, Wakabayashi K, et al. Effects of interleukin-1 beta on hippocampal glutamate and GABA releases associated with Ca2+-induced Ca2+-releasing systems. Epilepsy Res. 2006;71:107-16.

52. Matin N, Tabatabaie O, Falsaperla R, Lubrano R, Pavone P, Mahmood F, et al. Epilepsy and innate immune system: a possible immunogenic predisposition and related therapeutic implications. Hum Vaccin Immunother. 2015;11:2021-9.

53. Ravizza T, Noe F, Zardoni D, Vaghi V, Sifringer M, Vezzani A. Interleukin converting enzyme inhibition impairs kindling epileptogenesis in rats by blocking astrocytic IL-1b production. Neurobiol Dis. 2008;31:327-33.

54. Youn HS, Lee JY, Fitzgerald KA, Young HA, Akira S, Hwang DH. Specific inhibition of MyD88-independent signaling pathways of TLR3 and TLR4 by resveratrol: molecular targets are TBK1 and RIP1 in TRIF complex. J Immunol. 2005;175:3339-46.

55. Gao HM, Hong JS. Why neurodegenerative diseases are progressive: uncontrolled inflammation drives disease progression. Trends Immunol. 2008:29:357-65.

56. Hernandes MS, D'Avila JC, Trevelin SC, Reis PA, Kinjo ER, Lopes LR, CastroFaria-Neto HC, Cunha FQ, Britto LR, Bozza FA. The role of Nox2-derived ROS in the development of cognitive impairment after sepsis. J Neuroinflammation. 2014;11:36

57. Akarsu ES, Ozdayi S, Algan E, Ulupinar F. The neuronal excitability timedependently changes after lipopolysaccharide administration in mice: possible role of cyclooxygenase-2 induction. Epilepsy Res. 2006;71:181-7.

58. Ho YH, Lin YT, Wu CW, Chao YM, Chang AY, Chan JY. Peripheral inflammation increases seizure susceptibility via the induction of neuroinflammation and oxidative stress in the hippocampus. J Biomed Sci. 2015;22:46.

59. Wang Q, Qian L, Chen SH, Chu CH, Wilson B, Oyarzabal E, et al. Post-treatment with an ultra-low dose of NADPH oxidase inhibitor diphenyleneiodonium attenuates disease progression in multiple Parkinson's disease models. Brain. 2015;138:1247-62.

\section{Ready to submit your research? Choose BMC and benefit from:}

- fast, convenient online submission

- thorough peer review by experienced researchers in your field

- rapid publication on acceptance

- support for research data, including large and complex data types

- gold Open Access which fosters wider collaboration and increased citations

- maximum visibility for your research: over $100 \mathrm{M}$ website views per year

At BMC, research is always in progress.

Learn more biomedcentral.com/submissions 